\title{
Enduring Legacies of Empire: A Case Study of a Preservice Teacher's Feminist Resistance
}

\author{
Yvonne Brown \\ yvonnebrown08@sympatico.ca
}

\begin{abstract}
Drawing on lived experiences and recent literature, especially, research by Nurse, a University of the West Indies academic, this article shows how memory, experience, place and history can reveal continuities in the civilizing mission of colonial and imperial projects. In order to validate my major claims, I excerpt a vignette from my published memoir regarding personal experiences at a predominantly, male teacher's college in Jamaica (1962-1965).

At the college, I deliberately engaged in a complex set of oppositional and strategic performances which led to my becoming the student of the year when I graduated. In a larger context, such performances are strategies which assertive women may wish to adopt, in order to disrupt the hegemony of male dominated educational institutions in Canada and the Caribbean.
\end{abstract}

\section{Introduction}

From time to time, my colleague, Cecille DePass and I engage actively, in long telephone conversations in which we share memories of the land of our birth. Our imaginative, dialogic reflections occur, usually, when we want to explain the hegemonic social, cultural, and linguistic ideologies of the British Empire that we notice still operate, implicitly and explicitly, in policies and practices associated with Canadian education and schooling. We note with a sense of irony that a similar colonial pattern existed when we were schooled in Jamaica, over fifty years ago.

During one of our conversations, I remarked that notions and practices of male supremacy, male privilege, and sexism still persisted in the education systems. Further, that they provide gale force winds for the contemporary educational storm, in schools and universities, where now dialogue emerges concerning male underachievement internationally. Moreover, these concepts are embedded in jet streams which support the constructs and practices of white male supremacy and religious patriarchy, of one or other mainstream religion. In Jamaica and Canada, we are most familiar with heated, on -going debates concerning the continuing role of patriarchy.

This article illustrates the legacies of colonization, gender inequalities and slavery, within education. It reflects on the ways in which immigrants live and work with a kind of double vision. They are able to flash back and forth between the histories and geographies of 'back home' and 'the old country' with that of the new home in Canada and encounter in both locales the heritage of physical and cultural colonization.

The article is divided into three sections. Section 1 synthesizes the historical links between Canada and the Caribbean. Section 2 summarizes Keith Nurse's concept of masculinism, as being particularly relevant to gender relationships in postcolonial Jamaica. Section 3 illustrates Nurse's concept with an extract from my published memoir (2010).

Cultural and Pedagogical Inquiry, Fall 2016, 8(2), pp. 1-10

ISSN 1916-3460 @ 2016 University of Alberta

http://ejournals.library.ualberta.ca/index.php/cpi/index 


\section{Tracing the Colonial History of Jamaica \& Canada}

Canada and Jamaica share a lengthy history of well-established economic linkages within the former British and French Empires. For hundreds of years, close links have existed for Jamaica with Britain since 1666. In Canada contact with Europeans began in the early 1500's. Empire gradually, has spread its greedy tentacles initially, from the western Atlantic, (Maritimes), moving progressively, westwards across the Prairies of British North America, to the Pacific Coast.

Both Jamaica and Canada have played significant roles and functions in terms of economic, political, social and cultural building, consolidation and longevity of the British Empire. An empire which became the pre-eminent world power, reaching its zenith during Queen Victoria's lengthy reign. At present, Jamaica and Canada are part of a loosely affiliated Commonwealth, where there are remnants of economic ties and a sense of a shared colonial history.

Invaluable transatlantic trades were integral to the success of the British Empire. The Western Atlantic portions of the trade connected eastern Canada, the thirteen British American colonies of what became the USA, (after the American War of independence), and the British West Indies (BWI), with the UK. As importantly, there was a parallel trading pattern established between France and its colonies of New France (Quebec), and Haiti, Dominica and Guadeloupe in the Caribbean.

The important commodities traded to build Western Europe's empires were:

- Firstly, people, African bodies taken by force from continental Africa, who were destined to become, enslaved labourers on lucrative Caribbean, Southern USA and Latin

American sugar plantations. In Canada, it is not widely known, that household/domestic, African enslaved people were a part of the emerging, Anglo and Francophone colonies (Cooper, 2006). Household African slaves were also kept by a good number of the elite and middle class British people in the UK, until slavery was abolished in the 1830s. (Since 2015, British and Caribbean historians have made public a database which traces links between $18^{\text {th }}$ century, British and Euro-American slaves owners and their African descendants who are alive and well today. (Egs: Jennifer Newton, 2015; Hilary Beckles, 2013).

- Secondly, a vital part of the trade between Canada and the Caribbean was the exportation of dried, salted codfish from Newfoundland and the rest of the Maritimes (New Brunswick, Nova Scotia and Prince Edward Island) to feed the enslaved labour-force on plantations in the British West Indies, and in other European controlled Caribbean colonies.

- Thirdly, in return, molasses, sugar, rum, spices, hard tropical woods, and much later (in the $20^{\text {th }}$ century), with the introduction of refrigerated holds on ships, citrus and banana, were exported from the Caribbean to Canada, UK and USA.

Canada's trade with the Caribbean, also has a long-standing history. At the end of the American War of Independence, Great Britain's Navigation Acts blocked effectively, the lucrative trade between the former British colonies in the USA and the BWI. To fill the gap, Canada's trade with the Caribbean grew in importance, and accordingly, the volume of exports and imports 
increased significantly.

After World War Two, with the breakup of the British Empire, the Commonwealth of Nations was established. In many ways it was very similar to the old boys clubs associated with the English public school system. England representing the senior member while the former colonies were the newbies, the junior statesmen. Formed as a political and economic alliance, the Commonwealth maintained strong ties with Great Britain (GB), in terms of trade, social, cultural and educational links. The corresponding French political formation was the Francophonie. As a result of maintaining its strong colonial ties with GB and France, Canada has privileges associated with membership in both the English and French international organizations.

Today, Canada and Jamaica are prominent, proud and active members of the British Commonwealth of Nations. As importantly, Canada has become the home of thousands of Jamaican immigrants and their children. With the introduction of the point system, we were allowed entry, and came in significant numbers, after the elimination in 1967 of the restrictive immigration policy and system which favoured Europeans.

\section{The Legacy of Colonialism in Gender Relations and Education}

Within the specificity of the Jamaican context, the long term effects of slavery's machinations, meant that patriarchal rule resided only with the British planter class.

With a few exceptions, legal identities of slave children were assigned to their mothers, consistent with neither British of African traditions. As a result, the majority of the enslaved African males were emasculated. Hence, in the Caribbean it is understood that the construction of lost manhood replaced the types of patriarchy typically associated with West African cultures. Yet, a strong pro-masculine culture persists in Jamaica.

Caribbean social scientists, such as, Keith Nurse (in Reddock, 2004) support and adopt the theoretical construct, masculinism, rather than patriarchy, as a better way to explain gender relations in contemporary Caribbean milieus ${ }^{1}$. Nurse's insightful article entitled, "Masculinities in transition: gender and the global problematique", aptly states that:

Masculinism is the dominant philosophical value system in the gender framework. It is a totalizing philosophy in that it operates at a high level of consensus, as a well-constructed myth ... and as an instrument of disciplinary power. In the nature of myth, it goes largely uncriticized and unquestioned. The pervasiveness and seeming permanence of masculinism is explained by the fact that gender, like other arenas of oppression, "is not only 'out there' structuring activities and institutions: but also 'in here' - in our hearts and bodies structuring our intimate desires, our sexuality, our self-esteem, and our dreams." (Nurse in Reddock, 2004, p. 4).

Nurse continues in the vein of Foucauldian philosophy:

Cultural and Pedagogical Inquiry, Fall 2016, 8(2), pp. 1-10

ISSN 1916-3460 @ 2016 University of Alberta

http://ejournals.library.ualberta.ca/index.php/cpi/index 
Masculinism therefore operates as an instrument of disciplinary power through its surveillance, hierarchization, categorization and normalization of gender and global relations. (Nurse in Reddock, 2004, p. 7).

Noting this important point of departure from the North American feminist literature, I have revisited my experiences at the teacher's college, published in my memoir (2010). Nurse's social construct, masculinism, has provided a framework to re-interpret my teaching, learning and social experiences at the college. An illustrative vignette, below, applies Nurse's conceptual interpretation to my work. This construct has facilitated, augmented and expanded the historical explanations in my earlier published work.

In writing this article, ironically, the rub for me has been the more recent claim that Jamaican women have been privileged in the educational system; therefore, they are to blame for male educational and subsequent economic underachievement. Furthermore, that there is a crisis in education which demands special educational accommodations for male students.

I maintain that when young women eventually, gained access to secondary and tertiary education in Jamaica, no accommodation in curriculum or pedagogy was made because we were women. We had to learn to follow the existing educational and schooling policies, practices, rules and curriculum. We were forced to compete effectively, and we did. We were often harassed and bullied by male students and instructors in co-educational institutions. Mostly, we had many male teachers and principals who supported actively, the continued existence of a colonial, male dominated, educational system.

In schools and at colleges, we learned about 'everyman' and the universal human condition. Within this perspective, women were subsumed and made invisible by the use of generics terms such as man, mankind or men. We learned that it is sweet and fitting to fight and die for one's country, Great Britain. We learned and paid tribute to the Jamaicans who fought and died for Britain in World Wars I and II. We sang Anglican hymns at school and college assemblies. (Eg: Rachel Manley (1997), Austin Clark (2005), and Norma Girvan's, curated photographic exhibition in Ottawa which paid tribute to Jamaican and Caribbean soldiers who fought in the Two World Wars for the British). We learned about the hero's quest as the warrior soldier, and that a woman was made to be man's helpmate, (created from his rib), and accordingly, in every sense of the term, to be a subservient subject unto him. We learned such lessons, despite living and seeing at close quarters, families in which women were often the breadwinners and the drudges, the mules, who worked tirelessly, from dawn to dusk.

In my memoir, "Dead Woman Pickney" (2010), I explain what it was like for me to attend a predominantly male teacher's college, (founded in 1835, prior to the abolition of slavery), which trained Jamaican male teachers who would one day also, become lay preachers in the communities to which they were assigned. After the abolition of slavery, the Jamaican male teacher's mission was to participate actively, in the post-emancipation colonial project to Christianize and civilize the children of the former slaves. By the 1960s when I attended college, this mission was implicit.

Cultural and Pedagogical Inquiry, Fall 2016, 8(2), pp. 1-10

ISSN 1916-3460 @ 2016 University of Alberta

http://ejournals.library.ualberta.ca/index.php/cpi/index 
I dedicated a chapter to documenting my formal and non-formal educational sojourn at the teacher's college during my time there. An excerpt from that chapter is quoted towards the end of this article. It highlights some of the major obstacles I had to overcome in order to achieve the highest academic prizes, and to become the first female student of the year in the college's history. When I graduated, I won all the male trophies and even the coveted Lushington Memorial Prize for stellar academic performance. ${ }^{2}$

\section{Being a Female in the Jamaican Post-Colonial Education System}

In 1962 when I entered college, it was with the largest cohort of women ever to be admitted to the premier male teacher's college in the country. By sheer coincidence, we entered college, just a month after the country's independence celebrations. A time when the country was at the height of its euphoria of achieving political independence. In effect, Jamaican men had achieved their goal to join 'the brotherhood of man'. The country (and its male representatives), by joining the UN for example, had become 'equal among nations'. It was taken for granted that the Christian patriarchs would be in charge of the new nation. In fact, the first Jamaican Governor General, Sir Clifford Campbell was a retired educator, a graduate of the college. He was the keynote speaker at my graduation in 1965.

In 1962, the University College of the West Indies (until then, a College of the University of London) became a fully-fledged and autonomous university, the University of the West Indies (UWI). At this time, UWI began major curriculum reforms, specifically, introducing Caribbean content and perspectives in several disciplines. In the Faculty of Arts, (Departments of History and Literature), it introduced postcolonial studies and the works of Caribbean scholars. Nurse's contemporary research on masculinism is an example of a continuing emphasis on Caribbean studies.

As a student, I deliberately engaged in a complex set of oppositional and strategic performances. In doing so, I challenged conventional, British Christian roles for colonized native women and women teachers. I questioned notions of femininity. Understandably, my challenges to the assigned colonial roles were quite at odds with views of order and superior masculinity which were prescribed by the Old Testament patriarchs.

Without the development and visible expressions of critical theological consciousness, colonial men and women played out carefully constructed scripts of the masculinist worldview associated with a total, educational colonial institution. By the tenets of this worldview, women and children were invisible, subservient, 'seen and not heard'.

In the New Testament, women were represented as being above reproach. Mary, the mother of Jesus, was depicted as being innocent and pure. In this image, she was deprived of the fullness of her being. By eliminating her sexuality, from the official record, Mary is depicted as being the passive, bloodless, lifeless vessel capable of giving a virgin birth in a stable 'all forlorn'.

It is obvious that the writers of the Nativity story were men without any knowledge of grave, often deadly dangers associated with childbirth. (The typical images, usually portray, Mary, very shortly after giving birth, as serenely beaming at her son, who is wrapped in swaddling bands,

Cultural and Pedagogical Inquiry, Fall 2016, 8(2), pp. 1-10

ISSN 1916-3460 @ 2016 University of Alberta

http://ejournals.library.ualberta.ca/index.php/cpi/index 
lying on straw in a manger, with even the animals, looking on with reverence). Interestingly, as the story of the Nativity travelled from northeast Africa, across Europe, increasingly, being appropriated by western European church fathers, thinkers, painters, and stain glass artisans that the 'holy family' gradually, lost their northeast African phenotypical features. They become European in appearance. (As depicted, in Christmas cards, stain glass windows, murals and nativity crèches in churches and cathedrals).

In terms of iconic Old Testament narratives, militant and lecherous patriarchs were invoked and presented with unctuous, reverence in schools. They were sacred messengers, prophets and instruments of God. From time to time, such representatives were juxtaposed with a few women who were depicted as being, nursemaids, handmaids, seductresses, betrayers and slaves. In Biblical chapters, women filled subservient roles. For example, we learn of Adam and Eve in the creation story but there is no mention of Lilith in the same story in King James' authorized version of the Bible. Other well known pairings are David and Bathsheba and not David and Abigail; Samson and Delilah; John the Baptist and Salome.

Moses, as the deliverer of the enslaved, people of Israel was immortalized in epic films, such as, the "Ten Commandments" but there is no mention of the story of Judith, the deliverer of her people at another time, in Hebrew history. Such stories were the bases of the Bible which we had to learn, and on which we were examined. Biblical narratives were canonical literature and unquestioned doctrine to be internalized. We were expected to order our moral life according to the highest Christian ethics, and to unquestioningly accept and recite such maxims, as 'the bible does not lie'. These patriarchal lessons were fundamental in learning, teaching and social interactions in Jamaica of the 1960's.

Some fifty years after women entered the college, their statistical representation has changed significantly. Initially a 2:1 ratio in favour of men, has been disrupted. Women have become the majority, as they have become at the UWI in all faculties once considered male domains, ranging from medicine and law to the social sciences and humanities.

Yet, at the teacher's college, despite the significant majority of women in the student and instructor ranks, the institution's administrative, governance and formal ceremonial structures still remain the same as when I attended. A few examples to illustrate my point include:

- The college song which dates back to its early $19^{\text {th }}$ century pattern of male dominance, is still sung on ceremonial occasions, such as the investiture of male principals.

- For a number of years, despite women representing the majority of participants in all sports events, an important performance script remains the lusty, recitation of the male motto at all competitive games.

\section{Vignette: Masculinism in Action}

A vignette from my memoir illustrates well, the ways in which several men, as representatives of a dominant male educational institution, objected to the presence of women, in their private preserve. ${ }^{3}$ The vignette, occurred early in my residential college years. It showcases Nurse's concept of masculinism:

Cultural and Pedagogical Inquiry, Fall 2016, 8(2), pp. 1-10

ISSN 1916-3460 @ 2016 University of Alberta

http://ejournals.library.ualberta.ca/index.php/cpi/index 
During the second week of orientation, the second-year students joined us. It was their job to "rag" us and to reduce us to the slimy grubs and grubbesses that, as lowly first-year men and women, we should properly understand ourselves to be. I had never seen such two-legged barbarians in my life. Commands issued by the men included the following: "Grubbess, get over here and butter the senior man's toast." "Don't you hear the senior man's orders?" "Grubbess, get down and polish my shoes." "Who do you think you are, grubbess?" "You are nothing but a slimy little paramecium." "You were nothing but a little monkey in the zoo with the senior man"(this, referring to a date at the Hope Botanical Gardens that I had had with a senior man whom I knew before entering college).

I would have none of their boorishness, and I disobeyed every command. These second-year men chose every opportunity to torment me and to try to "cut me down to size." I was provoked at breakfast time at the ----- Hall dining table, at mid-morning teatime, at lunch hour, at afternoon tea break, and after classes. I would not give an inch. Their objective was to humiliate and intimidate me until I broke down and cried. By the conventions of ragging, it was supposed to end at the end of orientation. The intention was that by this time we timid newcomers would have been broken and made docile. Some of the men were alleged to be identifying their female "love interest" through this process. If they were trying to impress me as he-men, they could not have been more mistaken-I thought of them only with contempt. The word went out that they were going to "swing" this grubbess from the -----Tower. To be "swung" was to be publicly humiliated as in the spectacle of the public hangings during slavery days. -----Tower was the highest point on the campus. "Swing" me they did.

The bullying clowns kept up this ragging for six whole weeks, culminating in a show-down one Friday afternoon when some twenty or thirty second-year men swarmed me in front of ----- Hall and the Science Block as I was on my way home. Those third-year men, who were not yet weaned off this animal-like behaviour but who would not openly indulge in ragging, took up positions as spectators on the second floor balcony of the Science Block to watch the swinging. These twolegged animals made a circle around me and started hurling commands and insults at me. When I refused to answer them and attempted to walk out of the circle, two men crisscrossed their legs and tried to have me step over. Of course, I would not attempt to do that because they would not have hesitated to trip me and to have my skirt above my head. Men were shouting commands from all directions of the circle: "Grubbess! Don't turn your back on the senior man." "Grubbess! I am talking to you, look at me." Their anger and frustration at my obstinacy boiled to a menacing chant: “Cry, grubbess, cry; cry, grubbess, cry.” Like hell! I was not going to give such cowardly creatures the satisfaction of seeing me cry in front of them.

At the moment when I was uncertain as to how all of this was going to end, a senior gentleman, Mr. Fairweather, walked up to the circle of angry men and attempted to lead me out of the circle. By the rules of deference to the senior man, they should have stopped, stepped aside, and permitted us safe passage, so to speak. Instead, a few true "wooli- gans" kept on shouting insults at me. Two of the men again crossed their legs, trying to trip me. Mr. Fairweather stood firm, stared them down, and they retreated reluctantly. I was both scared and angry. If I had the physical prowess, I would have thrown feminine modesty and respectability to the wind and vanquished each one with my bare hands and the fire of my rage. Writing this now, I can discern echoes from slavery days. Was this a re-enactment of the public humiliation or the whipping of the rebel woman?

Mr. Fairweather and I walked in dead silence to ----- Road, the women's residence about a mile away from the campus. I was so full of tears; I could not open my mouth to thank him. I would not have him see me cry for all his gallantry and compassion. I just bowed low and shook his hand. I have remained grateful to this day for Mr. Fairweather's chivalry. I went straight to my bed and 
cried in my pillow for hours. I fell asleep, resolved to pack my suitcase and leave the next day. But where, oh where, would I go? I weighed the future possibilities of staying against going away to nowhere. I stayed. (Brown, 2010, pp. 157-158.

I do not know if ragging and such aggressive bullying continues; it would be worth finding out. My strategy of resistance and retaliation, as noted earlier was to outshine and outperform all of the men in all of my academic courses and competitions.

I perceive that male dominance still continues. In participating in a recent anniversary celebration of the teacher's college, now a university, I noted the persistence of explicit assumptions and patterns of ascribed male superiority and dominance. For example, in terms of their assumed right that men will chair, speak at panel presentations, and in follow up discussions, despite a sizeable number of women being present at all formal conference activities. Why were the women so reluctant to participate? Were the lessons of patriarchy still at work? Towards the end of the conference, I simply had to disrupt, such a pattern of male arrogance. I spoke out. 


\section{Endnotes}

1. From the research and publications of the UWI's, Gender and Development Studies Department, have come two interdisciplinary publications that were particularly, relevant and helpful. The specific publications were edited by: Rhoda E. Reddock (2004); and Eudine Barriteau (2003).

2. When I set out to research and write an auto-ethnography in the early 2000s, I was then, residing and teaching on Coast Salish Territory on the West Coast of Canada, for nearly three decades. I spent some 25 years in a Faculty of Education, at the University of British Columbia, in various capacities: undergraduate and graduate student, student advisor, lecturer, and finally in policy analysis for internationalization of teacher education. In writing this article, I revisited my memoir in order, to probe for deeper meanings about the gendered aspects of my education in Jamaica, as importantly, I wanted to explore long standing interests regarding the legacies of slavery, colonialism, and globalization.

3. Specific names of the college, institutional buildings and streets have been removed. I have kept Mr. Fairweather's name because he was the only student willing to intercede on my behalf. 


\section{References}

Barriteau, E. (2003). Ed. Confronting Power: Theorizing Gender: Interdisciplinary Perspectives in the Caribbean. Mona: UWI Press.

Beckles, H. McD. (2013). Britain's Black Debt: Repatriations for Caribbean Slavery and Native Genocide. University of the West Indies Press.

Brown, Y. (2010). Dead Woman Pickney. Kitchener, Waterloo: Wilfrid Laurier University Press.

Brown, Y. (2005). Bodies, Memories, and Empire: Life Stories About Growing up in Jamaica 1943-65. Unpublished, Doctoral Dissertation: University of British Columbia.

Clarke, A. (2005). Growing Up Stupid Under the Union Jack: A Memoir. Toronto: Thomas Allen Publishers.

Cooper, A. (2006). The Hanging of Angelique and the Untold Story of Slavery in Canada and the Burning of Old Montreal. HarperCollins Publishers Ltd.

Klingberg, F. J. (1939). The lady Mico Charity schools in the British West Indies, 1835-1842. The Journal of Negro history, 24(3), (pp. 291-344).

Kurlansky, M. (1997). Cod: A Biography of the Fish that Changed the World. Toronto, Ontario: Alfred A. Knopf Canada.

Manley, R. (1997). Drumblair: Memories of a Jamaican Childhood. Toronto: Vintage Canada.

Mintz, S. (1985). Sweetness and power: The place of sugar in modern history. New York: Viking Press.

Mintz, S. (1974). Caribbean transformations. New York: Columbia University Press.

Newton, J. (2015). Did your ancestors own slaves? New investigation reveals how 46,000 Brits were involved in the evil trade---just like the relatives of the Camerons, Benedict Cumberbach and Ben Affleck. Daily Mail, Online, updated, 17 November.

Nurse, K. (2004). Masculinities in Transition: Gender and the Global Problematique. In Rhoda Reddock. Interrogating Caribbean Masculinities: Theoretical and Empirical Analyses. Mona: UWI Press.

Reddock, R. E. (2004). Interrogating Caribbean Masculinities: Theoretical and Empirical Analyses. Mona: UWI Press.

Cultural and Pedagogical Inquiry, Fall 2016, 8(2), pp. 1-10

ISSN 1916-3460 @ 2016 University of Alberta

http://ejournals.library.ualberta.ca/index.php/cpi/index 